\title{
The influence of country of origin on purchase intention with specific reference to apparel fitting
}

\author{
A. Rashid ${ }^{1)}$ and L. Barnes ${ }^{2)}$
}

1) Nottingham Business School, Nottingham Trent University, Burton Street Nottingham, NG1 4BU |+44 (0)115848 2745

2) The University of Manchester, The University of Manchester, Oxford Road, Manchester, M13 9PL | Tel. +44(0)161306 3810

\section{Introduction:}

Country of origin has long been of interest to many researchers (e.g. Phao, 1993; Kalicharan, 2014; Yunus and Rashid, 2016). In part, this is because consumers evaluated the quality of a product based on where it was manufactured, and this became an important issue with the majority of fashion product production taking place in developing countries. Consequently, country of origin as a branding tool became an important factor in the fashion industry (Lee et al., 2013). Previously, numerous studies have suggested that consumers' perception of, and association with, country of origin are influenced by different factors, such as social, environmental and political factors and the workmanship of the country in question (e.g. Insch and McBride, 2004; Jiménez and Martín, 2012; Lee et al., 2013; Mostafa, 2015). For example, Rashid and Barnes (2017) identified the influence the media industry has on the perception of a country's image, i.e. the influence of a factory collapse in Bangladesh in 2013 (Bolle, 2014). In the same vein, studies on the country of origin effect have also found the influence that the halo and summary effects have on the product evaluation. For example, if consumers were less familiar with fashion products made in Indonesia, they would naturally infer the product attributes using the general image of Indonesian-made products, and thus rate the product based on their perception of the country as a whole (see also Kotabe and Helsen, 2009). In contrast, when consumers are familiar with a country's products (i.e. fashion designers in Paris), a summary construct model operates in which consumers develop a country's image from its product information, which then indirectly influences product perception (Han, 1989). In other words, a product naturally receives a positive attitude because of the perception of a country's products. Moreover, studies have also examined the impact of patriotism and ethnocentric behaviour on association with country image. More recently, authors, e.g. Rashid et al. (2016) and Barnes and Rashid (2017), have also made a contribution towards managerial perspectives and issues relating to the country of origin impact on the fashion industry. However, no research to date has examined the influence of country of origin on purchase intention with specific reference to apparel fitting. 


\section{Apparel fitting:}

Over the past two decades, authors have shown increasing interest towards the fit of apparel (e.g. Otieno et al., 2005; Apeagyei et al., 2007; Holmlund et al., 2011). For example, Shim and Bickle (1993) examined women 55 years and older as catalogue shoppers and their differences in satisfaction with the fit of apparel purchased through catalogues and found that the satisfaction level was relatively low for the entire sample of 872 respondents. Some of the key issues identified were that garment fits did not accommodate body proportions for the older market, especially those who did not fit sizes that were tailored for petit or plus sizes. Consequently, it is evident that age is an important factor in apparel fitting. Furthermore, Alexander et al. (2007) pointed out the issue of personal judgement on how a garment looks on the body. Finally, other factors have also been raised, such as fit association with comfort, body-cathexis (feelings about one's body) and symbolic meanings in social interactions. Adding to this, Rahman et al. (2017) has also added how consumers often evaluate the product on the basis of descriptive, inferential, informational and/or visual cues, and these can be classified as extrinsic or intrinsic cues. "Extrinsic cues" are a product's physical structure or appearance, such as price, brand name and country of origin, whereas intrinsic cues are inherent to the physical composition of a product such as fabric, fit, colour and style.

Moreover, authors have very recently also looked at apparel fitting issues in online fashion retailing (Miell et al., 2017) and technologies linked to fitting, such as 3D body scanners in a retail store (Lewis and Loker, 2016). However, the apparel fit and size association with country of origin remains an under-researched area.

\section{Research design:}

As this study aims to explore country of origin association from an apparel fitting perspective, a qualitative interpretivist approach is adopted (Creswell, 2007; Welch et al., 2011). This is a significant contribution to the country of origin study, as previous country of origin studies from consumer perspectives have prominently been quantitative in nature (e.g. Insch and McBride, 2004; Jiménez and Martín, 2012). Participants for study will be chosen using a judgemental approach, in particular female shoppers who consider fitting an important factor when deciding on the brand from which to purchase a product. To carry out the study, the project will use face-to-face semi-structured interviews. The semi-structured interview questions derive from the country of origin literature and are influenced by theory planned behaviour model (TBP) (Azjan, 1991), taking into account both individual and social factors that may influence customer intention and attitude towards apparel fitting and its association and or perception of a country. Interviews will last between 60 and 90 minutes and will be conducted by the researchers from March 2018 to September 2018. To analyse the data, a thematic analysis approach will be utilised to develop an understanding of the meaning, as interpreted by participants. 


\section{Discussion and conclusion:}

The data collection for this study will help address the gap regarding how consumers deem fit as one of the important factors influencing purchasing behaviour, but also their perception of how they associate a fit of a product with the country of origin of different fashion brands. The findings will make a contribution to the literature on country of origin, fashion branding and product management. The study may also introduce practical implications on how to make the service better in a fashion retail setting, where apparel fit is becoming an issue. Thus, the study may also add knowledge to the literature on service marketing.

\section{References:}

Ajzen, I. (1991) The theory of planned behavior. Organ. Behavior and Human Decision Processes. Pp. 179-211.

Alexander, M., Connell, L. J. and Presley, B. A. (2005) "Clothing fit preferences of young female adult consumers", International Journal of Clothing Science and Technology, Vol. 17 Issue: 1, pp.52-64,

Apeagyei, P. R., Otieno, R., and Tyler, D. (2007) "Ethical practice and methodological considerations in researching body cathexis for fashion products", Journal of Fashion Marketing and Management: An International Journal, Vol. 11 Issue: 3, pp.332-348.

Bolle M (2014) Bangladesh apparel factory collapse: background in brief. Congressional research service. CRS report. https://digital.library.unt.edu/ark:/67531/metadc463476/m1/1/high_res_d/R43085_2 014Jan10.pdf.

Chao, P. (1993) Partitioning country-of-origin effects: Consumer evaluations of a hybrid product. Journal of International Business Studies, Issue: 24, pp. 291-30.

Creswell, J.W. (2007), Qualitative Inquiry and Research Design, London: Sage Publications Ltd.

Holmlund,M., Hagman, A., and Polsa, p. (2011) "An exploration of how mature women buy clothing: empirical insights and a model", Journal of Fashion Marketing and Management: An International Journal, Vol. 15 Issue: 1, pp.108-122.

Insch, G.S. and McBride, J.B. (2004) The impact of country-of-origin cues on consumer perceptions of product quality: A binational test of the decomposed country-of-origin construct. Journal of Business Research, Vol. 57 Issue:3, pp.256-265. 
Jiménez, N. and Martín, S.S. (2012) Emerging Markets Commerce: The Role of CountryofOrigin and Animosity in Purchase Intention. International Journal of Business and Management, Vol. 7 Issue:17, p.34.

Kalicharan, H. D. (2014) 'The Effect And Influence Of Country-Of-Origin On Consumers Perception Of Product Quality And Purchasing Intentions', International Business \& Economics Research Journal, Vol. 13 Issue:5, pp. 897-902.

Kotabe, M. and Helsen, K. (2009) The SAGE Handbook of International Marketing. SAGE Publication: London, UK.

Lee, W.J., Phau, I., and Roy, R. (2013) “ Bonds ” or “ Calvin Klein ” Consumer ethnocentric and brand country origin effects towards men's underwear. Journal of Fashion Marketing and Management, Vol. 17 Issue: 1, pp. 65-84.

Lewis, T. L. and Loker, S (2017) “Trying on the Future : Exploring Apparel Retail Employees' Perspectives on Advanced In-Store Technologies," Fashion Practise. 9370, pp.1-25.

Mostafa, R.H.A. (2015) The Impact of Country of Origin and Country of Manufacture of a Brand on Overall Brand Equity. International Journal of Marketing Studies, Vol. 7 Issue: 2, pp.70-83.

Otieno, R., Harrow, C., and Lea-Greenwood, G. (2005) "The unhappy shopper, a retail experience: exploring fashion, fit and affordability", International Journal of Retail \& Distribution Management, Vol. 33 Issue: 4, pp.298-309,

Rahman, O., Benjamin C.M. Fung, B. C.M Chen, Z., and Gao, X (2017) "A crossnational study of apparel consumer preferences and the role of product-evaluative cues", Asia Pacific Journal of Marketing and Logistics, Vol 29, Issue:4, pp.796-812.

Rashid A., Barnes L. (2017) Country of Origin: Reshoring Implication in the Context of the UK Fashion Industry. In: Vecchi A. (eds) Reshoring of Manufacturing. Measuring Operations Performance. Springer, Cham.

Rashid, A., Barnes, L. and Warnaby, G. (2016). Management perspectives on country of origin. Journal of Fashion Marketing and Management. Vol 20, Issue: 2, pp. 230-244.

Shim, S., Bickle, M.C., (1993). Women 55 years and older as catalog shoppers: satisfaction with apparel fit and catalog attributes. Clothing and Textiles Research Journal. Vol.11, pp. 5364. 
Welch, C., Piekkari, R., Plakoyiannaki, E., and Paavilainen-Mantymaki, E., (2011). Theorising from case studies: Towards a pluralist future for international business research. Journal of International Business Studies, Vol. 42, pp. 740-762.

Yunus, N. S. N. M., \& Rashid, W. E. W. (2016). The Influence of Country-of-origin on Consumer Purchase Intention: The Mobile Phones Brand from China. Procedia Economics and Finance, Vol. 37, pp. 343-349. 